https://helda.helsinki.fi

\title{
Accumulation of mercury in fish and man from reservoirs in Northern Finland
}

\author{
Lodenius, $\mathrm{M}$. \\ D. Reidel Publishing Co. \\ 1983
}

Lodenius, M. et al. 1983. Accumulation of mercury in fish and man from reservoirs in Northern Finland. Water, Air and Soil Pollution 19: 237-246.

http://hdl.handle.net/1975/198

Downloaded from Helda, University of Helsinki institutional repository.

This is an electronic reprint of the original article.

This reprint may differ from the original in pagination and typographic detail.

Please cite the original version. 


\title{
ACCUMULATION OF MERCURY IN FISH AND MAN FROM RESERVOIRS IN NORTHERN FINLAND
}

\author{
MARTIN LODENIUS, ARI SEPPÄNEN, and MATTI HERRANEN \\ Department of Environmental Science, University of Helsinki, SF-00710 Helsinki 71. Finland
}

(Received January 19, 1982; Revised April 14, 1982)

\begin{abstract}
Fishing is of great importance in northern Finland, where large water-control projects have been constructed. Increased $\mathrm{Hg}$ content in fish from recently impounded reservoirs has stimulated an investigation of possible accumulation of $\mathrm{Hg}$. Therefore, samples of fish and human hair have been analyzed for $\mathrm{Hg}$ content. The concentrations of $\mathbf{H g}$ in fish from man-made lakes were higher than in fish from a background (natural) lake. Fish of prey, burbot (Lota lota) and pike (Esox lucius) contained more $\mathrm{Hg}$ ( $\max$ $2.0 \mathrm{mg} \mathrm{kg}{ }^{-1}$ ) than other species of fish and higher values were recorded in the flesh than in the liver. In the Porttipahta reservoir the $\mathrm{Hg}$ content of burbot and pike exceeded the Finnish safety limits of 0.5 and $1 \mathrm{mg} \mathrm{kg} \mathbf{~ k}^{-1}$. In samples of human hair there was also a clear difference between persons living near man-made lakes (meằn $4.9 \mathrm{mg} \mathrm{kg}^{-1}$ ) and background (mean $1.6 \mathrm{mg} \mathrm{kg}^{-1}$ ) areas. The highest concentrations (about $30 \mathrm{mg} \mathrm{kg}{ }^{-1}$ ) were found in hair samples from middle-aged people eating substantial amounts of fish from reservoirs. The concentrations were higher in males than in females probably caused by a higher fish consumption.
\end{abstract}

\section{Introduction}

In recent years elevated $\mathrm{Hg}$ concentrations have been found in fish from recently impounded reservoirs (Abernathy and Cumbie, 1977; Bodaly and Hecky, 1979; Cox et al., 1979; Meister et al., 1979; Verta, 1982). In northern Finland extensive water control projects have been built. The fishing in the new man-made lakes has become important for the local people. For these reasons it seemed necessary to study the effect of water control on the $\mathrm{Hg}$ content in fish and man. Human hair has been widely used as an indicator of $\mathrm{Hg}$ exposure and there has in general been agood correlation between the consumption of polluted fish and the $\mathrm{Hg}$ content of hair (Sumari et al., 1972; Nuorteva et al., 1975; Harada et al., 1977; Ohtsuka and Suzuki, 1978; Suzuki et al.,1979; Phelps et al., 1980).

\section{Material and Methods}

\subsection{STUDY AREAS}

Fish and hair samples were obtained from eight areas in northern Finland (Figure 1):

\subsubsection{Lokka}

The ground under this reservoir consisted of $60 \%$ open fens, $30 \%$ marsh land and $10 \%$ forests. The annual mean temperature in the Lokka-Porttipahta area is $-1.5^{\circ} \mathrm{C}$ (Franssila and Jarvi 1974). The filling of the reservoir started in 1967. The maximum allowed 


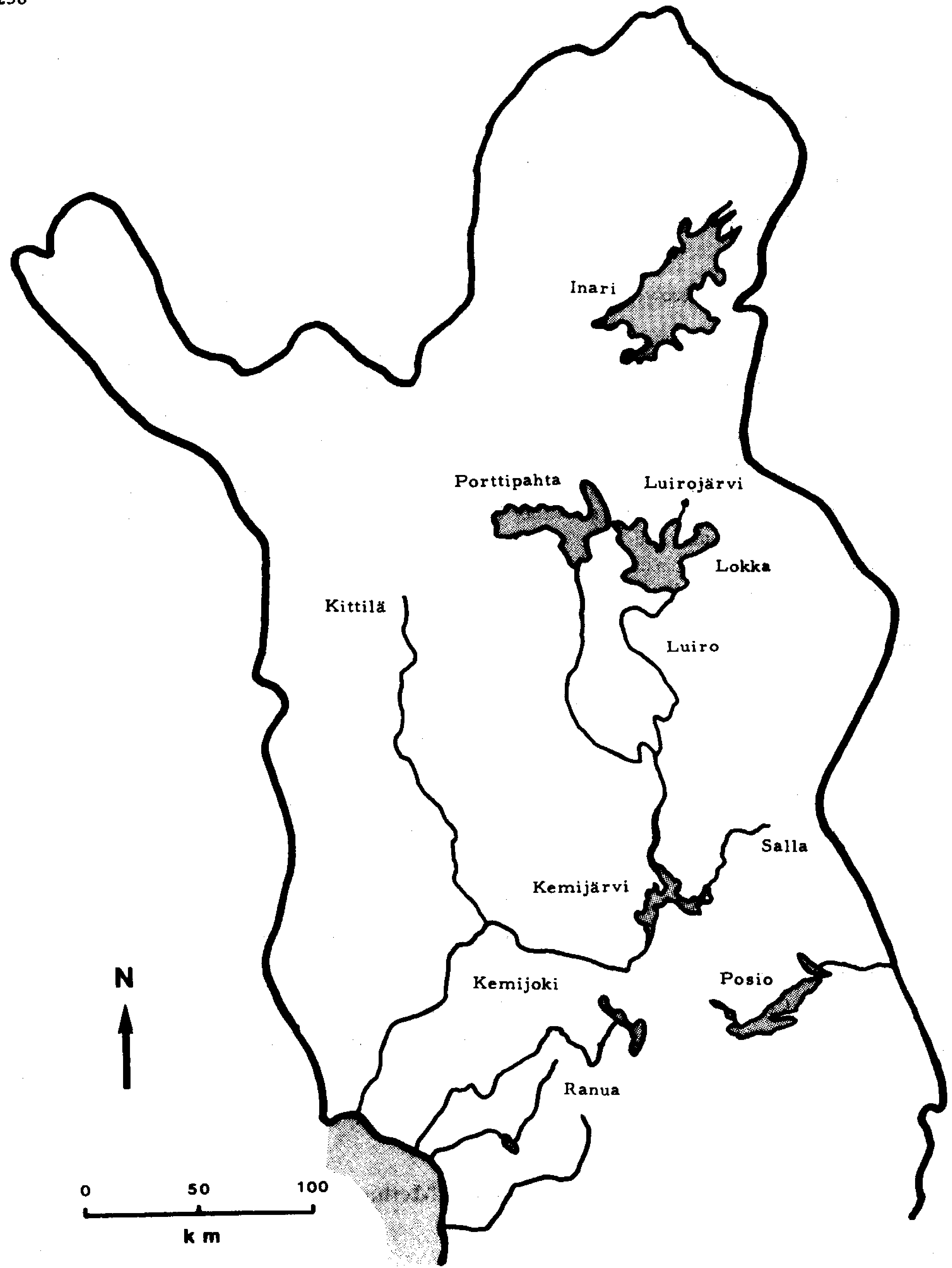

Fig. 1. The study areas.

fluctuation in water level is $5 \mathrm{~m}$ and the volume varies from 500 to $2063 \times 10^{6} \mathrm{~m}^{3}$. At the minimum water level about $200 \mathrm{~km}^{2}$ of the bottom are exposed. The water is

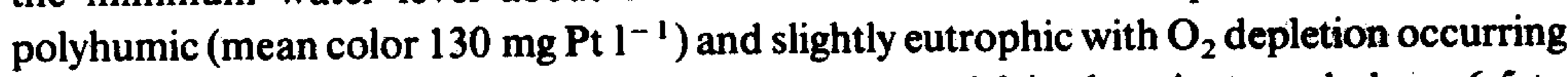
periodically. The pH-value is normally about 6.0 to 6.2 in the winter and about 6.5 to 6.7 in the summer (Heinonen and Airaksinen, 1974). 
In the year 1977 the fish catch from Lokka was $183000 \mathrm{~kg}$ (Anon., 1979). The most important species in 1979 were (as a percentage of the total fish catch): pike $(43 \%)$, perch $(22 \%)$, ide $(13 \%)$, whitefish $(12 \%)$ and burbot $(6 \%)$ (Mutenia, 1981$)$.

\subsubsection{Porttipahta}

About half of the ground under this reservoir consisted of bogs (Nenonen and Nenonen, 1972).

The filling of the reservoir started in 1970. The maximum allowed water level fluctuation is $11 \mathrm{~m}$ and the volume is 150 to $1353 \times 10^{6} \mathrm{~m}^{3}$. At the minimum water level about $180 \mathrm{~km}^{2}$ of the bottom are exposed. The water is polyhumic (color about $150 \mathrm{mg}$ $\mathrm{Pt}^{-1}$ ) and a little more oligotrophic than in Lokka. Oxygen depletion may occur. The pH-value varies normally between 6.3 and 6.8 being thus somewhat higher than in Lokka (Heinonen and Airaksinen, 1974).

The fish catch in the year 1977 was $85000 \mathrm{~kg}$ (Anon., 1979) and the most important fish species in 1979 were: perch $(50 \%)$, pike (34\%) and burbot (12\%) (Mutenia, 1981).

\subsubsection{Kemijärvi}

Lake Kemijärvi and the river Kemijoki about $45 \mathrm{~km}$ above Kemijärvi are strongly controlled. Kemijärvi receives water from the Lokka and Porttipahta reservoirs. The maximum allowed water level fluctuation is $7 \mathrm{~m}$ and the variations in water quality are extensive due to the control and natural factors (Nenonen, 1978).

\subsubsection{Control Areas}

The waters in the Salla, Posio and Ranua areas are unpolluted, oligotrophic and oligohumic lakes and rivers. Hair samples were also obtained from the following areas: Sodankylă, Rovaniemi, Kittilă, and Inari. The background fish samples originate from Luirojărvi, a small unpolluted lake situated above the Lokka reservoir.

\subsection{Fish AND HAIR SAMPLES}

Altogether 159 fish samples were obtained from Lokka, Porttipahta, Kemijărvi and Luirojărvi. Samples of the dorsal, axial muscle and, if possible, the liver were taken and the length and weight of the fish were measured.

The people involved in this investigation cut their hair samples according to detailed instructions and sent the samples by mail to the laboratory. They also filled in a questionnare concerning their age, sex, fish eating habits and other possible sources of $\mathrm{Hg}$ contamination. A fish consumption index (FCI in the tables) was calculated on the basis of the answers. In this index

$0=$ no fish consumption,

$1=1$ fish meal a week or less,

$2=2-4$ fish meals a week, and

$3=$ more than 4 fish meals a week. 
Altogether 111 hair samples were obtained. If possible the hair samples were divided in $1.5 \mathrm{~cm}$ long segments starting from the scalp.

\subsection{Mercury analysis}

The samples were digested with $5 \mathrm{ml}$ of concentrated nitric and sulphuric acids $(1: 4)$ in a water bath $\left(+60^{\circ} \mathrm{C}\right)$ and analysed using cold vapor atomic absorption spectrometry (Coleman MAS-50).

\section{Results}

The total fish consumption was almost the same in all the areas investigated (Table I) and fish consumption was higher for males (mean FCI 2.2) than for females (mean FCI 1.5). However, there were significant differences in the distribution of fish species in the diet in different areas. In Lokka, Porttipahta and Kemijarvi (reservoirs) the people ate more pike and burbot than in the background areas. There was no significant difference in the composition of the fish consumption between males and females.

\section{TABLE I}

The total fish comsumption (FCI 0-3 as described in the text) and the percentage distribution of species in the fish diet in 7 areas according to the answers to the questionnare.

\begin{tabular}{lllllll}
\hline Area & FCl & Pike & Burbot & Perch & Whitefish & Other species \\
\hline Lokka & 1.6 & 32 & 13 & 16 & 28 & 11 \\
Porttipahta & 2.0 & 24 & 18 & 19 & 30 & 9 \\
Kemijärvi & 2.0 & 36 & 20 & 16 & 14 & 14 \\
Salla & 1.6 & 19 & 11 & 19 & 26 & 25 \\
Posio & 2.1 & 10 & 0 & 18 & 25 & 47 \\
Ranua & 1.9 & 34 & 3 & 35 & 4 & 24 \\
Other areas & 2.1 & 20 & 10 & 24 & 23 & 23 \\
\hline
\end{tabular}

The highest $\mathrm{Hg}$ contents in fish were found in burbot and pike from Porttipahta (Table II). In the other reservoir areas, Lokka and Kemijarvi, the concentrations were also higher than in the background lake, Luirojärvi. In most fish species there was less $\mathrm{Hg}$ in the liver than in the flesh. In whitefish, however, the relationship was the reversed (Table III).

There were no significant differences in the sex or age distribution of the people from the various areas investigated. In the reservoir areas the $\mathrm{Hg}$ content in human hair was three times higher than in the background areas (Table IV). Mercury concentrations exceeding $15 \mathrm{mg} \mathrm{kg}^{-1}$ were found only in reservoir areas, where the maximum values exceeded $30 \mathrm{mg} \mathrm{kg}^{-1}$. The $\mathrm{Hg}$ concentration in hair was 1.8 times higher in males than in females. The highest values were found in people eating lots of fish from reservoir waters. There was a positive correlation between the total fish consumption and the $\mathrm{Hg}$ content in hair in the reservoir areas $(r=0.343, p<0.01)$ and in the whole material $(r=0.256, p<0.01)$ but not in the background areas $(r=0.173)$. 
TABLE II

Mercury content ( $\mathrm{mg} \mathrm{kg}^{-1}$ fresh weight) in fish ffesh from different areas in northern Finland

\begin{tabular}{|c|c|c|c|c|c|}
\hline \multirow{2}{*}{$\begin{array}{l}\text { Area } \\
\text { Lokka }\end{array}$} & \multirow{2}{*}{$\begin{array}{l}\text { Species } \\
\text { Pike (Esox lucius) }\end{array}$} & \multirow{2}{*}{$\frac{n}{14}$} & \multirow{2}{*}{$\begin{array}{l}\text { Weight, } g \\
\bar{x} \text { (range) } \\
1004(250-2750)\end{array}$} & \multicolumn{2}{|c|}{$\begin{array}{l}\text { Mercury, } \mathrm{mg} \mathrm{kg}^{-1} \\
\bar{x} \text { (range) }\end{array}$} \\
\hline & & & & 0.32 & $(0.09-0.77)$ \\
\hline & Perch (Perca fluviatilis) & 29 & $329(155-770)$ & 0.24( & $<0.02-0.48)$ \\
\hline & Ide (Leuciscus idus) & 7 & $694(225-820)$ & 0.15 & $(0.10-0.20)$ \\
\hline \multirow{5}{*}{ Porttipahta } & Pike (Esox lucius) & 9 & $1031(500-1860)$ & 0.50 & $(0.10-0.83)$ \\
\hline & Burbot (Lota lota) & 26 & $922(350-2100)$ & 0.70 & $(0.26-2.0)$ \\
\hline & Perch (Perca fluviatilis) & 1 & 300 & 0.32 & \\
\hline & Roach (Rutilus rutilus) & 2 & $230(200-260)$ & 0.32 & $(0.30-0.33)$ \\
\hline & Whitefish (Coregonus lavaretus s.l.) & 16 & $605(520-680)$ & 0.20 & $(0.07-0.34)$ \\
\hline \multirow[t]{5}{*}{ Kemijärvi } & Pike (Esox lucius) & 11 & $1049(380-2400)$ & 0.38 & $(0.18-0.75)$ \\
\hline & Burbot (Lota lota) & 5 & $2130(500-4000)$ & 0.30 & $(0.21-0.40)$ \\
\hline & Perch (Perca fluviatilis) & 2 & $160(150-170)$ & 0.15 & $(0.12-0.17)$ \\
\hline & Ide (Leuciscus idus) & 2 & $270(270)$ & 0.13 & $(0.10-0.16)$ \\
\hline & Whitefish (Coregonus lavaretus s.l.) & 3 & $217(170-300)$ & 0.07 & $(0.06-0.08)$ \\
\hline \multirow[t]{4}{*}{ Luirojärvi } & Pike (Esox lucius) & 1 & 200 & 0.04 & \\
\hline & Burbot (Lota lota) & 11 & $855(300-2200)$ & 0.20 & $(0.10-0.48)$ \\
\hline & Roach (Rutilus rutilus) & 7 & $30(20-40)$ & 0.20 & $(0.14-0.24)$ \\
\hline & Whitefish (Coregonus lavaretus s.l.) & 13 & $96(50-300)$ & 0.05 & $(0.03-0.08)$ \\
\hline
\end{tabular}

TABLE III

Mercury content ( $\mathrm{mg} \mathrm{kg}^{-1}$ fresh weight) in fish liver from different areas in northern Finland

\begin{tabular}{|c|c|c|c|c|c|}
\hline Area & Species & $n$ & $\begin{array}{l}\text { Weight, } g \\
\bar{x} \text { (range) }\end{array}$ & $\begin{array}{l}\text { Merc } \\
\bar{x}(\text { ral }\end{array}$ & $\begin{array}{l}\mathrm{ry}, \mathrm{mg} \mathrm{kg}^{-1} \\
\mathrm{ge)}\end{array}$ \\
\hline Lokka & $\begin{array}{l}\text { Pike (Esox lucius) } \\
\text { Perch (Perca fluviatilis) } \\
\text { Ide (Leuciscus idus) }\end{array}$ & $\begin{array}{r}6 \\
12 \\
1\end{array}$ & $\begin{array}{l}933(250-2750) \\
309(155-550) \\
740\end{array}$ & $\begin{array}{l}0.17 \\
0.16 \\
0.07\end{array}$ & $\begin{array}{l}(0.10-0.27) \\
(0.07-0.42)\end{array}$ \\
\hline Porttipahta & $\begin{array}{l}\text { Pike (Esox lucius) } \\
\text { Burbot (Lota lota) } \\
\text { Perch (Perca fluviatilis) } \\
\text { Roach (Rutilus rutilus) } \\
\text { Whitefish (Coregonus lavaretus s.l.) }\end{array}$ & $\begin{array}{r}9 \\
24 \\
1 \\
2 \\
6\end{array}$ & $\begin{array}{l}1031(500-1860) \\
918(350-2100) \\
300 \\
230(200-260) \\
591(520-650)\end{array}$ & $\begin{array}{l}0.32 \\
0.27 \\
0.10 \\
0.16 \\
0.52\end{array}$ & $\begin{array}{l}(0.14-0.45) \\
(0.12-0.68) \\
(0.14-0.18) \\
(0.22-1.0)\end{array}$ \\
\hline Kemijärvi & $\begin{array}{l}\text { Pike (Esox lucius) } \\
\text { Burbot (Lota lota) } \\
\text { Perch (Perca fluviatilis) } \\
\text { Ide (Leuciscus idus) } \\
\text { Whitefish (Coregonus lavaretus s.l.) }\end{array}$ & $\begin{array}{l}5 \\
4 \\
2 \\
2 \\
3\end{array}$ & $\begin{array}{l}896(380-1500) \\
2538(750-4000) \\
160(150-170) \\
270(270) \\
217(170-300)\end{array}$ & $\begin{array}{l}0.13 \\
0.08 \\
0.08 \\
0.05 \\
0.06\end{array}$ & $\begin{array}{l}(0.10-0.18) \\
(0.04-0.10) \\
(0.07-0.09) \\
(0.04-0.06) \\
(0.03-0.12)\end{array}$ \\
\hline Luirojärvi & $\begin{array}{l}\text { Pike (Esox lucius) } \\
\text { Burbot (Lota lota) } \\
\text { Whitefish (Coregonus lavaretus s.l.) }\end{array}$ & $\begin{array}{r}1 \\
11 \\
3\end{array}$ & $\begin{array}{l}200 \\
855(300-2200) \\
250(150-300)\end{array}$ & $\begin{array}{l}0.10 \\
0.08( \\
0.11\end{array}$ & $\begin{array}{r}<0.02-0.16) \\
(0.10-0.12)\end{array}$ \\
\hline
\end{tabular}




\section{TABLE IV}

Age, fish consumption and hair $\mathrm{Hg}$ content of the population in seven north Finnish areas. Fish consumption index (FCI) $0-3$ calculated as described in the text.

\begin{tabular}{|c|c|c|c|c|}
\hline & $n$ & $\begin{array}{l}\text { Age } \\
\bar{x}\end{array}$ & FCI & $\begin{array}{l}\left.\mathrm{Hg} \text { content ( } \mathrm{mg} \mathrm{kg}^{-1} \mathrm{~d} . \mathrm{w} .\right) \\
\bar{x} \text { (range) }\end{array}$ \\
\hline $\begin{array}{l}\text { Lokka } \\
\text { males } \\
\text { females }\end{array}$ & $\begin{array}{r}19 \\
11 \\
8\end{array}$ & $\begin{array}{l}43 \\
47 \\
38\end{array}$ & $\begin{array}{l}1.6 \\
1.9 \\
1.1\end{array}$ & $\begin{array}{l}4.4(<0.02-27) \\
5.6(0.58-27) \\
2.8(<0.02-11)\end{array}$ \\
\hline $\begin{array}{l}\text { Porttipahta } \\
\text { males } \\
\text { females }\end{array}$ & $\begin{array}{r}16 \\
10 \\
6\end{array}$ & $\begin{array}{l}45 \\
45 \\
45\end{array}$ & $\begin{array}{l}2.0 \\
2.1 \\
1.8\end{array}$ & $\begin{array}{ll}5.9 & (0.37-35) \\
6.4 & (0.67-35) \\
5.1 & (0.37-17)\end{array}$ \\
\hline $\begin{array}{l}\text { Kemijärvi } \\
\text { males } \\
\text { females }\end{array}$ & $\begin{array}{l}33 \\
18 \\
15\end{array}$ & $\begin{array}{l}49 \\
49 \\
48\end{array}$ & $\begin{array}{l}2.0 \\
2.0 \\
1.9\end{array}$ & $\begin{array}{ll}4.7 & (0.16-32) \\
5.2 & (0.41-32) \\
4.0 & (0.16-8.7)\end{array}$ \\
\hline $\begin{array}{l}\text { Salla } \\
\text { males } \\
\text { females }\end{array}$ & $\begin{array}{r}13 \\
6 \\
7\end{array}$ & $\begin{array}{l}57 \\
57 \\
57\end{array}$ & $\begin{array}{l}1.6 \\
2.0 \\
1.3\end{array}$ & $\begin{array}{l}1.9(<0.02-13) \\
1.4(<0.02-5.0) \\
2.4(<0.02-13)\end{array}$ \\
\hline $\begin{array}{l}\text { Posio } \\
\text { males } \\
\text { females }\end{array}$ & $\begin{array}{r}12 \\
5 \\
7\end{array}$ & $\begin{array}{l}44 \\
53 \\
37\end{array}$ & $\begin{array}{l}2.1 \\
2.2 \\
2.0\end{array}$ & $\begin{array}{ll}1.4 & (0.26-6.0) \\
1.8 & (0.43-6.0) \\
1.1 & (0.26-2.4)\end{array}$ \\
\hline $\begin{array}{l}\text { Ranua } \\
\text { males } \\
\text { females }\end{array}$ & $\begin{array}{l}9 \\
6 \\
3\end{array}$ & $\begin{array}{l}47 \\
49 \\
45\end{array}$ & $\begin{array}{l}1.9 \\
2.2 \\
1.3\end{array}$ & $\begin{array}{ll}1.2 & (0.15-12) \\
1.5 & (0.15-12) \\
0.72 & (0.36-0.94)\end{array}$ \\
\hline $\begin{array}{l}\text { Other areas } \\
\text { males } \\
\text { females }\end{array}$ & $\begin{array}{l}9 \\
6 \\
3\end{array}$ & $\begin{array}{l}52 \\
49 \\
57\end{array}$ & $\begin{array}{l}2.1 \\
2.7 \\
1.0\end{array}$ & $\begin{array}{ll}2.0 & (0.70-4.6) \\
2.2 & (0.70-4.6) \\
1.6 & (0.78-2.7)\end{array}$ \\
\hline
\end{tabular}

The highest $\mathrm{Hg}$ concentrations were found in middle-aged people (Figure 2). The variation in $\mathrm{Hg}$ contents of the hair segments taken at different distances from the scalp was great and no significant time-dependent trend could be observed.

\section{Discussion}

The observed $\mathrm{Hg}$ concentrations in burbot and pike, particularly from the Porttipahta reservoir, were higher than in fish from unpolluted north Scandinavian lakes (Johnels et al., 1967; Westoర and Rydalv, 1971; Sauvonsaari et al. 1979) and they are obviously caused by the construction and water control activities. The even distribution of $\mathrm{Hg}$ between muscle and liver indicates that the $\mathrm{Hg}$ is methylated (Johnels and Westermarck, 1969; Zelenko and Kosta, 1973; Kosta et al., 1974).

The source of $\mathrm{Hg}$ in new impoundments is apparently the inundated soil but it is not completely known how it is introduced to and accumulated in the limnetic foodchains.

In the soil, upward movements of $\mathrm{Hg}$ in pellicular water or as dissolved elemental vapor have been noted (Jonasson, 1973) and in Finland the $\mathrm{Hg}$ content in the top soil layer is higher (mean $0.10 \mathrm{mg} \mathrm{kg}^{-1}$ ) than in deeper layers (mean $0.02 \mathrm{mg} \mathrm{kg}^{-1}$ ) (Soveri, 


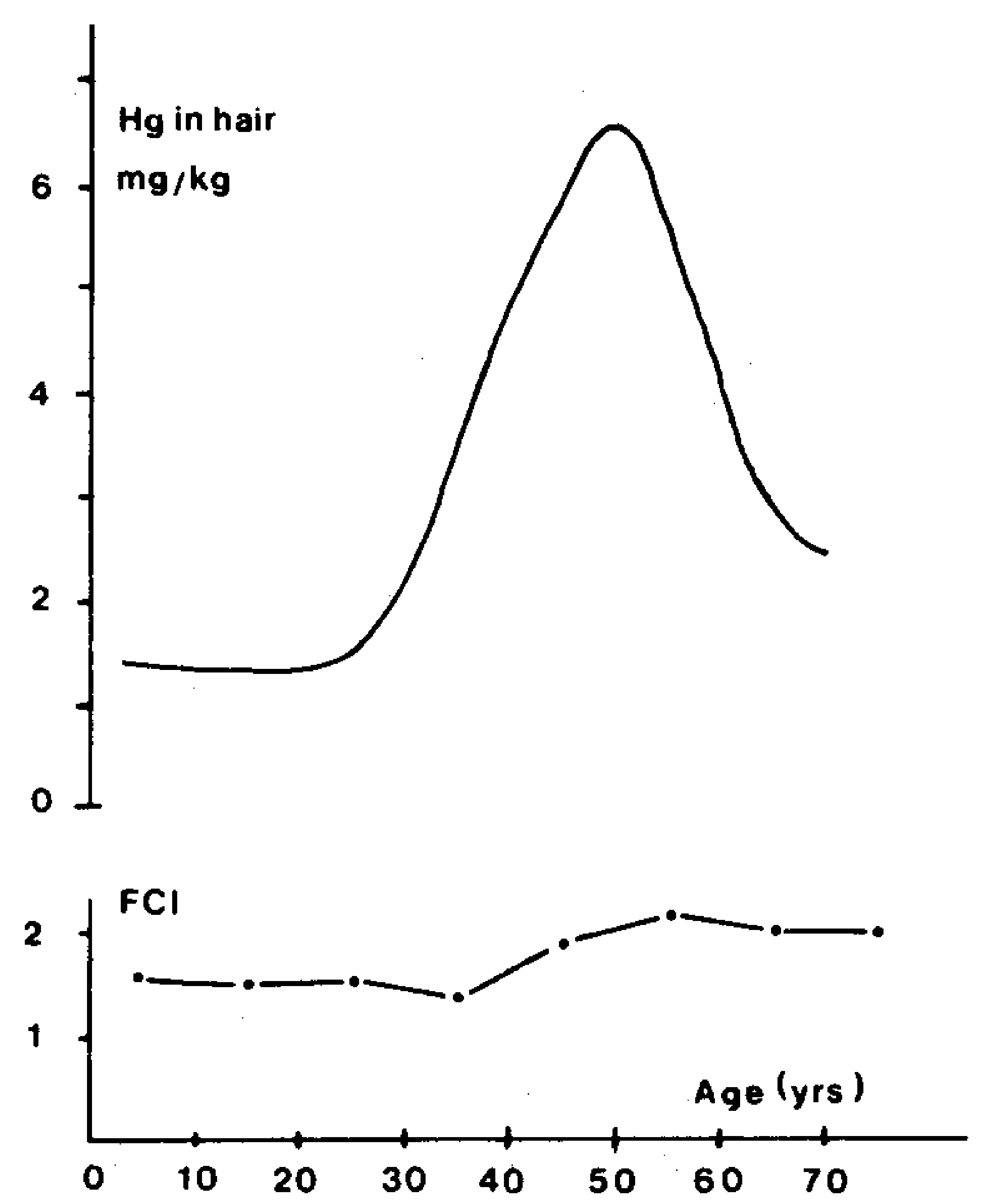

Fig. 2. Mercury content in hair and the fish consumption index $(0-3$, FCI as described in the text $)$ in different age groups (whole material).

1977). Physical mixing, microbial degradation of humic substances, methylation and gas ebullition may contribute to the mobilization of $\mathrm{Hg}$. Mercury may be very strongly but reversibly bonded to humic acid (Strohal and Huljev, 1974; Miller, 1975; Beneš et al., 1976; Jackson et al., 1980).

The sedimentation rate is very low in Finnish man-made lakes and the original vegetation and bottom structure are only slightly changed after $15 \mathrm{yr}$ of water control (Vogt, 1978). Anaerobic conditions periodically occurring in the reservoir bottom water promotes the formation of insoluble mercuric sulphide, which, however, is converted back to soluble, divalent $\mathrm{Hg}$ under aerobic conditions (Fagerström and Jernelöv, 1972). Microbial methylation of $\mathrm{Hg}$ may occur both under aerobic and anaerobic conditions (Bisogni and Lawrence, 1975). Meister et al., (1979) considered microbial activity as the main source of $\mathrm{Hg}$ release in new impoundments. When sediments are exposed to air the formation of volatile dimethylmercury may be very fast (Jernelöv et al., 1971), but no dimethylmercury seem to be formed under acidic conditions (Beijer and Jernelöv, 1979).

Even if the solubility of $\mathrm{Hg}$ decreases with increasing acidity (Schindler et al., 1980), a low $\mathrm{pH}$-value and a low bioproduction will promote an accumulation of $\mathrm{Hg}$ in biota (Brosset and Svedung, 1977; Björklund and Norling, 1979; Håkansson, 1980: Jackson et al., 1980) as will a high humus content in the water (Hultberg, 1978). The relatively high fish biomass in the man-made lakes of Lokka and Porttipahta implies a 'dilution' of the $\mathrm{Hg}$ circulating in the biota. As the methylation of $\mathrm{Hg}$ in new impoundments is fast (Bodaly and Hecky, 1979) and the elimination of $\mathrm{Hg}$ from organisms in cold water 
is slow (Ribeyre et al. 1980), the mercury concentrations in fish may stay at a high level. In large specimens of pike the decrease in $\mathrm{Hg}$ content after the cessation of $\mathrm{Hg}$ pollution may be quite rapid even if no decrease is observed in smaller specimens (Nuorteva et al., 1979).

Cox et al. (1979) estimated that the $\mathrm{Hg}$ content of fish in man-made lakes should be normal within ca. $5 \mathrm{yr}$ after the impoundment. Since the Lokka and Porttipahta reservoirs are 14 and $11 \mathrm{yr}$ old, respectively, it is obvious that the purification of these watercourses has taken much longer, and there are still quite high $\mathrm{Hg}$ concentrations in the fish.

The mobility of $\mathrm{Hg}$ in the environment seems to be much greater than formerly assumed. For example, high $\mathrm{Hg}$ concentrations have also been found in unpolluted areas in precipitation and freshwater biota (Koirthyohann et al., 1974; Delisle, 1979; Nuorteva and Soveri, 1979; Sherbin, 1979; Ohlin, 1980).

According to Finnish regulations, the $\mathrm{Hg}$ content of fish should not exceed $1 \mathrm{mg} \mathrm{kg}^{-1}$ wet weight, and if the $\mathrm{Hg}$ content is 0.5 to $1 \mathrm{mg} \mathrm{kg}^{-1}$, fish consumption should be restricted to $500 \mathrm{~g}$ per week. Burbot and pike weighing $1 \mathrm{~kg}$ exceeded the lower limit in Porttipahta while the larger specimens exceeded even the upper limit. Large pike from Lokka exceeded the lower limit. From this reservoir no burbot were obtained for analysis. In Kemijarvi the $0.5 \mathrm{mg} \mathrm{kg}^{-1}$ limit was exceeded only by the largest pike and in the background lake, Luirojärvi all the values were low.

A regular intake of $\mathrm{Hg}$ constitutes a health risk. Symptoms of methylmercury poisoning (Minamata-disease) may occur when hair $\mathrm{Hg}$ levels are $50 \mathrm{mg} \mathrm{kg}^{-1}$ or more, but symptoms may still appear when the $\mathrm{Hg}$ content in hair has diminished (Harada and Smith, 1975; Igata et al., 1975; Takeuchi and Eto, 1975). According to a Swedish expert committee (Berglund et al., 1970), the $\mathrm{Hg}$ levels in hair should not exceed $6 \mathrm{mg} \mathrm{kg}^{-1}$. In the reservoir areas the mean $\mathrm{Hg}$ concentration in hair was near this level and the maximum levels exceeded it 5-fold, but no values were at the level, where clinical symptoms appear. In the background areas only two samples of hair exceeded $6 \mathrm{mg} \mathrm{kg}^{-1}$.

\section{Acknowledgments}

Several persons have been involved in the collection of the samples. We are especially indebted to Dr Marjatta Rantala and Mr Heikki Melamies. We will also thank Prof. Pekka Nuorteva for valuable criticism concerning the investigation and the manuscript and Mr Robert Harper for checking of the language. The Academy of Finland has supported this investigation.

\section{References}

Abernathy. A. R. and Cumbie, P. M.: 1977, Bull. Environ. Contam. Toxicol. 17, 595.

Anon.: 1979. Riista- ja kalatalouden tutkimuslaitoksen kalantutkimusosaston tutkimus-, palvelu-, tiedotusja julkaisutoiminta vuonna 1978. (Research, service and information work, and publications of the Fisheries Division of the Finnish Game and Fisheries Research Institute in 1978.) 14. 1. 
Beijer, K. and Jernelöv, A.: 1979, 'Methylation of Mercury in Aquatic Environments', in Nriagu, J. O. (ed.), The Biogeochemistry of Mercury in the Environment, Amsterdam, New York, Oxford, 203-210.

Beneš, P., Gjessing, E. T., and Steinnes, E.: 1976, Water Res. 10, 711.

Berglund, F., Berlin, M., Birke, G., Cederlof, R., v. Euler, U., Friberg, L., Holmstedt, B., Jonsson, E., Lünnig, K. G., Ramel, C., Skerfving, S., Svensson, A, Tejning, S., and Holmqvist, S. E.: 1970, Nordisk Hyg. Tidskr. S1 suppl. $3,1-351$.

Bisogni, J. and Lawrence, A.: 1975, J. Water Pollut. Control Fed. 47, 135.

Björklund, J. and Norling, L.: 1979, Statens Naturvårdsverk PM 1090.

Bodaly, R. A. and Hecky, R. E.: 1979, Can. Fish. Mar. Serv. MS Rep. 1531, 1-15.

Brosset, C. and Svedung, I.: 1977, Swedish Water Air Pollut. Res. Lab. B378:1-13.

Cox, J. A., Carnahan, J., DiNunzio, J., McCoy, J. and Meister, J.: 1979, Bull. Environm. Contam. Toxicol. 23. 779.

Delisle, C. E., Kloppenburg; J., and Sylvain, J.: 1979, Eau de Québec 12, 76.

Fagerström, T. and Jernelöv, A.: 1972, Water Res. 6, 1193.

Franssila, M. and Järvi, P.: 1974, 'Lokan allasalueen ilmastosta', (Summary: On the climate of the Lokka basin.) in P. Rapeli (ed.), Lapin ilmastokirja - Climate of Lapland, Lapin tutkimusseura. Rovaniemi, pp. $48-60$.

Harada, M., Fujino, T., Akagi, T., and Nishigaki, S.: 1977, Kumamoto Med. J. 30, 57.

Harada, M. and Smith, A. M.: 1975, 'Minamata Disease: A Medical Report, in Smith, W. E. and Smith, A. M. (eds.), Minamata, Words and Photographs, Holt, Rinehart and Winston Inc., pp. 180-192.

Heinonen, P. and Airaksinen, E.: 1974, 'Lokan ja Porttipahdan tekojärvien tilan kehittymisestä vuosina 1971 - 1974', (Summary: Data on the water quality in Lokka and Porttipahta reservoirs during the years 1971-1974) Vesihallitus (Nat. Bd. Waters, Finland) Tiedotus (Rep.) 77, 1-51.

Hultberg, H.: 1978, 'Betydelsen av pH, humus- och saltinnehåll i sjövatten för kvicksilverförekomst i gädda Swedish Water Air Pollut. Res. Lab. 10.1.1978. mimeogr.. 9 p. + figs.

Håkansson, L.: 1980, Environ. Pollut. B1: pp. 285-304.

Igata, A., Niina, K., Hamada, R., and Ohkatsu, Y.: 1975, 'The Late Onset of Organic Mercury Intoxication After Exposure, in Tsubaki, T. (ed.): Studies on the Health Effects of Alkyl-Mercury in Japan, Environment Agency, Japan pp. 178-179.

Jackson, T. A., Kipphut, K., Hesslein, R., and Schindler, D. W.: 1980, Can. J. Fish. Aquat. Sci. 37, 387. Jernelöv, A., Lann, H., and Lord, M.: 1971, Vatten 27, 234.

Johnels, A. G. and Westermark, T.: 1969, 'Mercury Contamination of the Environment in Sweden', in Miller,

M. and Berg, G. (eds.): Chemical Fallout: Current research on persistent pesticides, Springfield, pp. 221-239.

Johnels, A. G., Westermark, T., Berg, W., Persson, P. I. and Sjöstrand, B.: 1967, Oikos 18, 323.

Jonasson, I. R.: 1973, Nature 241, 447.

Koirtyohann, S. R., Meers, R., and Graham, L. K.: 1974, Environ. Res. 8, 1.

Kosta, L., Byrne, A. R., Zelenko, V., Stegnar, P., Dermelj, M., and Ravnik, V.: 1974, Vestnik Slovenskega Kemijskega Drustva 21, 49.

Meister, J. F., DiNunzio, J., and Cox, J. A.: 1979, J. Am. Water Works Assoc. 71, 574.

Miller, R. W. 1975, Verh. Internat. Verein. Limnol. 19, 2082.

Mutenia, A.: 1981, Suomen Luonto 40, 262.

Nenonen, M.: 1978, 'Kemijoen vesistön veden laadusta ja ainevirtaamista. Kemijoen vesiensuojeluyhdistys, Rovaniemi. $26 \mathrm{pp}$.

Nenonen, O. and Nenonen, M.: 1972, Vesihallitus (Nat. Bd. Waters, Finland) Tiedotus (Rep.) 21, 1.

Nuorteva, P., Häsänen, E. and Nuorteva, S.-L.: 1975, Ympäristö ja Terveys 6, 611.

Nuorteva, P., Lodenius, M. and Nuorteva, S.-L.: 1979, Aquilo 19, 97.

Nuorteva. P. and Soveri, J.: 1979, Elohopeasade. Tammi, Helsinki, 177 pp.

Ohlin, B.: 1980, Vår Föda 32 suppl.: 159-197.

Ohtsuka, R. and Suzuki, T.: 1978, Ecol. Food Nutr. 6, 243.

Phelps, R. W., Clarkson, T. W., Kershaw, T. G., and Wheatley, B.: 1980, Arch. Environm. Health 35, 161.

Ribeyre, F., Delarche, A., and Boudou, A.: 1980, Environ. Pollut. Ser. B 1, 259.

Sauvonsaari, J., Takatalo, S., and Vaajakorpi, H.: 1979, Ympäristö ja Terveys 10, 342.

Schindler, D. W., Hesslein, R. H. Wagemann, R. and Broecker, W. S.: 1980, Can. J. Fish. Aquat. Sci. 37, 373.

Sherbin, I. G.: 1979, Mercury in the Canadian Environment, Environ. Canada, Environ. Prot. Serv. Rep. EPS 3-EC-79-6. $359 \mathrm{pp}$. 
Soveri, J.: 1977, Ympäristö ja Terveys 8, 118.

Strohal, P. and Huljev, D. 1971, Investigation of Mercury-Pollutant Interaction with Humic Acids by Means of Radiotracers, Nuclear Techniques in Environmental pollution. IAEA-SM-142a: 439.

Sumari, P., Partanen, T., Hietala, S., and Heinonen, O. P.: 1972, Work Environm. Health 9, 61.

Suzuki, T., Shishido-Kashiwazaki. S., Igata, A., and Niina, K.: 1979, Ecol. Food Nutr. 8, 117.

Takeuchi, T. and Eto, K.: 1975, 'Minamata Disease; Chronic Occurrence from Pathological Viewpoints', in Tsubaki, T. (ed.), Studies on the Health Effects of Alkyl-Mercury in Japan, Environment Agency, Japan. pp. 28-62.

Verta, M.: 1982, 'Tekoaltaiden kalojen elohopeapitoisuudet v. 1980 ja arvio pitoisuuksien kehittymisestä', Vesihallitus (Nat. Bd. Waters, Finland) Tiedotus (Rep.) 212, 1.

Westő, G. and Rydălv, M.: 1971, Vär Föda 23, 177.

Vogt, H.: 1978, Aqua Fenn. 8, 12.

Zelenko, V. and Kosta, L.: 1973, Talanta 20, 115. 